Bond University

Research Repository

\title{
Process Waste Analysis for Offsite Production Methods for House Construction: A Case Study of Factory Wall Panel Production
}

Ayinla, Kudirat; Cheung, Franco; Skitmore, Martin

Published in:

Journal of Construction Engineering and Management

DOI:

10.1061/(ASCE)CO.1943-7862.0002219

Licence:

Other

Link to output in Bond University research repository.

Recommended citation(APA):

Ayinla, K., Cheung, F., \& Skitmore, M. (2022). Process Waste Analysis for Offsite Production Methods for House Construction: A Case Study of Factory Wall Panel Production. Journal of Construction Engineering and Management, 148(1). https://doi.org/10.1061/(ASCE)CO.1943-7862.0002219

\section{General rights}

Copyright and moral rights for the publications made accessible in the public portal are retained by the authors and/or other copyright owners and it is a condition of accessing publications that users recognise and abide by the legal requirements associated with these rights.

For more information, or if you believe that this document breaches copyright, please contact the Bond University research repository coordinator. 


\section{Abstract}

10 There is a growing interest in the use of offsite manufacturing (OSM) in the construction industry

11 disregarding criticisms of lacking real improvement from some offsite approaches adopted by

12 housebuilders as compared to their onsite counterparts. Quantitative performance measures from

13 previous studies are based on conventional onsite methods, with little attention paid to the performance

14 and process improvements derived from various OSM methods.

15 In response, a case study was conducted based on two OSM methods using standardized and non-

16 standardized processes for the production stage of a factory-manufactured wall panel. Value system

17 analysis and root cause analysis using the 5Whys method was adopted to evaluate possible

18 improvements in terms of process waste. The study reveals that OSM production methods that replicate

19 site arrangements and activities involving significant manual tasks do not necessarily provide a marked

20 improvement from the conventional onsite method. Thus, there is a need to re-evaluate the processes

21 involved to eliminate such embedded process wastes as non-value-added time and cost and to consider automating critical activities. The analysis adopted in the case study provides measurable evidence of 
23 the performance gained from having a structured workflow over a non-structured workflow. It also

24 reveals how process wastes are generated in the production process of wall panels offsite.

25 Keywords: lean manufacturing; offsite manufacturing; process waste; process modeling; root cause 26 analysis, 5whys.

\section{Introduction}

28 Offsite manufacturing (OSM) methods are becoming increasingly popular in the housing and

29 construction sectors. OSM methods provide opportunities to exploit the lean production system in 30 manufacturing and achieve "lean construction" - a concept to reduce and eliminate wastes (including

31 both physical and process wastes) in the construction processes (Howell 1999, Dave et al. 2013). The

32 benefits of OSM have been widely studied, including reduced construction time, health and safety

33 risks, environmental impact and whole-life cost, increased quality, increased predictability,

34 productivity, whole-life performance, and profitability (Blismas et al. 2006, Pan et al. 2008, Pan and

35 Goodier 2012). According to Pasquire and Connolly (2002), these benefits are the outcome of process

36 improvements from implementing lean manufacturing in a factory environment. However, although

37 most of the benefits are linked to process improvements at the production phase, little attention has

38 been paid to how the choice production method may improve or reduce their acquisition.

39 It is reported that offsite manufacturing companies are inheriting lean manufacturing approaches in

40 their processes to minimize cost (Zhang et al. 2020) through optimization of the design and

41 construction processes by taking into account lean principles (Gbadamosi et al. 2019). This sometimes

42 necessitates various levels of automation to be implemented in OSM workflow to improve efficiency

43 and productivity (Zhang et al. 2016), including the introduction of robotic systems in production,

44 transportation, and assembly. While the offsite approach is continuously developing and advancing,

45 the process benefits from lean implementation may not be fully realized depending on the approaches to production adopted due to practices in OSM processes being similar to conventional onsite methods 
47 (Zhang et al. 2020). For instance, researchers (Pasquire and Connolly 2002, Zhang et al. 2020) have

48 reported non-standardized practices in OSM processes and emphasized the need to avoid repeating

49 'onsite practices under a roof'. This is because, compared to the traditional onsite method, OSM needs

50 to be taken as a process-oriented approach, where the benefits of standardization and repetitions can

51 be applied (Fernández-solís 2009). This implies the need for offsite manufacturers to take a process

52 view to establish and quantify improvements in their product development practices and to make

53 informed decisions on their choice of methods.

54 Several tools are available to support the analysis of processes. Of these, business process modeling $55(\mathrm{BPM})$ is used in various industries, such as Engineering, IT, and software development and

56 Manufacturing (Nurcan et al. 2005, Doomun and Jungum 2008, Shi et al. 2008). This aims to eliminate

57 functional boundaries - focusing on how things are done (the process) rather than what is done (the

58 product) (Barber et al. 2003). BPM is well recognized for its ability to facilitate a shared understanding

59 of the process by enabling an understanding and analysis of the product/service development process

60 of an organization (Aguilar-Savén 2004, Akasah et al. 2010). It enables the modeling of actual (AS-

61 IS) and proposed (TO-BE) processes in order to identify gaps in current practices and ways to address

62 them (Doomun and Jungum 2008). The TO-BE model mainly involves a computer-simulated

63 workflow, which provides anticipated results prior to investment, which in turn reduces the scheduling

64 and financial risks of an organization (Nikakhtar et al. 2015).

65 This study evaluates the alternative production methods of OSM by quantifying and analyzing the 66 process wastes embedded in these methods in practice, based on the activities involved in a typical

67 factory housebuilding process. Applying a case study approach containing two units of analysis (i.e., 68 two different OSM production methods representing the AS-IS and TO-BE processes), the root causes

69 of eight categories of the process waste from the two alternative production methods are analyzed

70 using business process modeling (BPM). The study contributes to presenting quantitative evidence of 
71 the performance of structured and non-structured OSM methods in terms of process waste, to support

72 informed production workflow design decision making.

\section{Process benefit realization of OSM method of construction}

74 Traditional construction activities are labor-intensive by nature with mainly the performance of

75 workers as a critical factor affecting productivity. OSM attempts to streamline and automate

76 production in a controlled factory environment. It adopts a lean manufacturing approach to optimize

77 production performance and efficiency (Vernikos et al. 2013, Gbadamosi et al. 2019). The benefits of

78 OSM can be grouped into five types: process, product, organizational, marketing, and

79 social/environmental benefits. The key aspects and examples of benefits for each type as identified in

80 past literature are summarised in Table 1. These benefits may explain why the construction industries

81 in many countries are being encouraged to standardize and automate the production processes through

82 the application of OSM.

83 The OSM workflow involves a variety of concurrent and iterative activities, structured production

84 sequences, and various levels of automation. It is significantly different from the activities,

85 construction sequence, and use of plant and machinery for conventional linear onsite workflow (Zhang

86 et al. 2020). OSM has been classified with respect to the product, process, and people (Gibb 1999, Arif

87 and Egbu 2010, Quale et al. 2012, Ayinla et al. 2019), which provides the necessary elements for

88 understanding the different systems in OSM. Although the various benefits are well recognized, the

89 adoption of OSM in practice has been slow. The approaches for evaluating alternative production

90 methods are not well understood. Also, there has been no quantification of the benefits of different

91 types of OSM methods through systematic evaluation.

92

93

4

(C) 2021 IEEE.

Personal use of this material is permitted. Permission from IEEE must be obtained for all other uses, in any current or future media, including reprinting/republishing this material for advertising or promotional purposes, creating new collective works, for resale or redistribution to servers or lists, or reuse of any copyrighted component of this work in other works. 
95 Table 1: Categories of OSM benefits

\begin{tabular}{|c|c|c|c|}
\hline Benefits & Key aspects & Example & Reference \\
\hline \multirow[t]{4}{*}{ Process benefits } & Time & $\begin{array}{l}\text { Improved delivery in terms of better } \\
\text { logistics due to fewer trades on site. } \\
\text { Delivery speed of up to } 50-60 \% \text { less } \\
\text { than conventional methods. }\end{array}$ & $\begin{array}{l}\text { (Miles and Whitehouse } \\
\text { 2013). }\end{array}$ \\
\hline & Productivity & $\begin{array}{l}\text { Standardisation and economy of scale. } \\
\text { Improved working environment and } \\
\text { less distractions. } \\
\text { Incorporation of some sort of } \\
\text { automation. }\end{array}$ & $\begin{array}{l}\text { (Pasquire and Connolly } \\
\text { 2002, Gibb and Isack } \\
\text { 2003, Eastman and Sacks } \\
\text { 2008, Pan and Sidwell } \\
\text { 2011, Quale et al. 2012) } \\
\end{array}$ \\
\hline & Safety & $\begin{array}{l}\text { Increased occupational health and } \\
\text { safety by improved working } \\
\text { conditions. } \\
\text { Dry construction process. }\end{array}$ & $\begin{array}{l}\text { (Pasquire and Connolly } \\
\text { 2002, Bertelsen 2005, } \\
\text { Höök and Stehn 2008, } \\
\text { Lawson } \text { et al. 2010, Kolo } \\
\text { et al. 2014). }\end{array}$ \\
\hline & Performance & $\begin{array}{l}\text { Lean production approach: } \\
\text { standardising processes that leads to } \\
\text { formalised procedures, specialisation } \\
\text { and a controlled production process. }\end{array}$ & $\begin{array}{l}\text { (Pasquire and Connolly } \\
\text { 2002). }\end{array}$ \\
\hline \multirow[t]{2}{*}{ Product benefits } & Quality & $\begin{array}{l}\text { Better quality products resulting from } \\
\text { improved working conditions and } \\
\text { quality management. }\end{array}$ & $\begin{array}{l}\text { (Gorgolewski 2005, } \\
\text { Larsson and Simonsson } \\
\text { 2012). }\end{array}$ \\
\hline & Cost & $\begin{array}{l}\text { Lower unit cost of components as a } \\
\text { result of savings from mass production } \\
\text { and standardisation. } \\
\text { Increased cost certainty. }\end{array}$ & (Ozaki 2003), \\
\hline Organisational benefits & Management & $\begin{array}{l}\text { Project management and programme } \\
\text { improvements also termed "the } \\
\text { structural factor". }\end{array}$ & (Zakaria et al. 2018). \\
\hline Marketing benefits & $\begin{array}{l}\text { Client } \\
\text { satisfaction }\end{array}$ & $\begin{array}{l}\text { Client satisfaction as a result of mass } \\
\text { customisation - that allows customers } \\
\text { to interact with OSM suppliers and } \\
\text { building relationships in the exchange. }\end{array}$ & (Cheung et al. 2016). \\
\hline \multirow[t]{3}{*}{$\begin{array}{l}\text { Social/environmental } \\
\text { benefits }\end{array}$} & Waste & $\begin{array}{l}\text { Waste reduction as OSM presents the } \\
\text { advantage of executing projects with } \\
\text { minimal amount of waste generation. }\end{array}$ & $\begin{array}{l}\text { (Höök and Stehn 2008, } \\
\text { Arif and Egbu 2010, Quale } \\
\text { et al. 2012, Mao et al. } \\
\text { 2013, Shamsuddin et al. } \\
\text { 2013). }\end{array}$ \\
\hline & Impact & Environmental impact reduction. & $\begin{array}{l}\text { (Gorgolewski 2005, } \\
\text { Nahmens and Ikuma } \\
\text { 2012). }\end{array}$ \\
\hline & Health & Improved health and safety practices. & (Pan and Sidwell 2011). \\
\hline
\end{tabular}

96 According to Lawson et al. (2010), OSM can take the form of simply replicating the onsite method,

97 or automating activities using line manufacturing similar to automotive production. Automation is one

98 core aspect for productivity gain, and OSM methods can be classified into four categories according

99 to the level of automation involved: 
- Static method - where prefabricated elements are manufactured in one position, and materials, services and personnel are brought to the fabrication point. This mostly replicates the onsite construction method in a factory environment.

- Linear method - where the process is sequential and carried out in a discrete number of individual stages. Most activities are carried out manually by factory operatives.

- Semi-automated linear method - which shares the same principles as the linear method but tends to have more dedicated stages and individual tasks may be automated.

- Automated linear method - which comprises linear production with fully automated sequential stages.

Although the four categories may be very similar, or identical, major tasks and products as a result,

their activities and production and assembly specifications (such as resource requirement, information

111 flow, and sequences of activities) can vary significantly. Previous studies (e.g., Pasquire and Connolly

112 2002, Zhang et al. 2020) criticized the approach by housebuilders using the static method as not

113 realizing the full benefit of offsite production, and simply carrying out the manufacturing process as a

114 'mini construction project' in an enclosed space, thus replicating onsite construction inefficiencies. On

115 the other hand, largely automating activities may not be always beneficial. This is due to the general

116 trade-off between the level of automation in design and the amount of investment required to facilitate

117 automation. Yet, while the static method may result in low productivity, it is flexible and arguably can

118 be used to produce products with a wider range of designs. This poses the question of which benefits

119 from Table 1 are obtained from which OSM methods, especially in the process category.

120 Previous research related to the evaluation of OSM methods in construction work includes studies of 121 their approach to applying lean and the critical success factors involved (Meiling et al. 2012, Pearce 122 et al. 2018), strategies for integrating offsite production technologies (Pan et al. 2012), barriers to lean 123 implementation (Shang and Sui Pheng 2014), company's lean thinking implantation (Zhang et al.

6 
124 2016) and design processes with reference to lean principles (Gbadamosi et al. 2019). These studies

125 have typically evaluated the OSM approach at a high level. One aspect that has not been well

126 researched is the process benefits acquired in terms of waste embedded in the competing OSM

127 production methods.

128 Process waste in lean manufacturing

129 The traditional mass production line, known as the 'push system', contains standardized parts that are 130 processed following a station-by-station plan. This can lead to an unsynchronised flow of processes, 131 and often overproduction as a result (Wilson 2010). In contrast, the lean manufacturing method 132 implements a 'pull system', involving such concepts as pulling products forward and a single unit flow 133 (Howell and Ballard 1998). Implementing a balanced and synchronized operation helps reduce waste 134 in the process and prevents inventory build-up as the process flows smoothly. The term 'lean' is used 135 to denote 'less' resources (Koskela 1992). Lean manufacturing aims to minimize process waste and 136 maximize value by meeting service demands with minimal inventory. In practice, it relies on the use 137 of a set of tools that assist in the identification and steady elimination of process waste (Howell and 138 Ballard 1998), which arises from activity-centered thinking (Howell 1999).

139 Process waste in this regard is anything in addition to the minimum requirement for a business 140 operation to function, i.e., the minimum amount of equipment, materials, and manpower vital to 141 production. Previous studies suggest that there are five major aspects of minimization: material, 142 investment, inventory, space, and people (Wilson 2010). Process waste can be classified into seven 143 categories as summarised in Table 2 (Melton 2005, Wahab et al. 2013, Nikakhtar et al. 2015). 144 However, some researchers (e.g. Wahab et al. 2013) have argued that there should be additional waste 145 relating to people's ability not being fully utilized: thus, leading to an additional category of "unused 146 or underused talent" as explained in Table 2. Process waste can also be classified according to (i) waste 147 generated from non-value-adding activities (NVA), and (ii) unavoidable waste generated due to the 
149 due to product quality, health and safety, or specific customer requirements. Thus, they are necessary 150 non-value-adding activities (NNVA). For an activity carried out in a process to be considered value151 adding (VA), three criteria must be fulfilled: (i) it must physically transform the product a step further, 152 (ii) the customer must be willing to pay for the change, and (iii) it must be correctly carried out with 153 no need for rework (Wilson 2010).

154 Table 2: Different types of process waste in manufacturing processes

\begin{tabular}{|c|c|c|}
\hline Type & $\begin{array}{l}\text { Description } \\
\end{array}$ & $\begin{array}{l}\text { Example of cause } \\
\end{array}$ \\
\hline $\begin{array}{l}\text { Overproduction } \\
\quad \text { (OP) }\end{array}$ & $\begin{array}{l}\text { Production of excess product thus leading } \\
\text { to other types of waste such as the need to } \\
\text { store, transport, inventory and rework on } \\
\text { the waste. }\end{array}$ & $\begin{array}{l}\text { - Result of making products too early. } \\
\text { - } \quad \text { Products that cannot be sold due to defects. } \\
\text { - Imbalanced production process }\end{array}$ \\
\hline $\begin{array}{l}\text { Waiting } \\
\text { (W) }\end{array}$ & $\begin{array}{l}\text { Workers being ideal for whatever reasons } \\
\text { either in the short or long term not adding } \\
\text { value to the customer. }\end{array}$ & $\begin{array}{l}\text { - Short-term waiting as a result of an unbalanced line } \\
\text { - Long-term waiting for results from this, such as } \\
\text { waiting due to machine failure. } \\
\text { - Intermediate product waiting for processing. } \\
\text { - Large amount of work in progress (WIP) inventory }\end{array}$ \\
\hline $\begin{array}{l}\text { Transportation } \\
\text { (T) }\end{array}$ & $\begin{array}{l}\text { Moving parts around between processing } \\
\text { steps, production lines and shipping } \\
\text { products to the end consumers. }\end{array}$ & $\begin{array}{l}\text { - Moving pallets of intermediate products within the } \\
\text { factory or between/to site } \\
\text { - Movement of materials continuously before final } \\
\text { destination }\end{array}$ \\
\hline $\begin{array}{l}\text { Over-processing } \\
\text { (P) }\end{array}$ & $\begin{array}{l}\text { Processes/steps in product development } \\
\text { beyond the needs of customers. }\end{array}$ & $\begin{array}{l}\text { - Over specification } \\
\text { - Overdesign } \\
\text { - Iterative design } \\
\text { - } \quad \text { Poor and inefficient processing equipment }\end{array}$ \\
\hline $\begin{array}{l}\text { Movement } \\
\text { (M) }\end{array}$ & $\begin{array}{l}\text { Unnecessary and non-value-adding } \\
\text { movement of people. Active workers } \\
\text { looking busy does not equate to adding } \\
\text { value to a product or process. }\end{array}$ & $\begin{array}{l}\text { - Looking for tools or materials } \\
\text { - } \quad \text { Inefficient workstation design }\end{array}$ \\
\hline $\begin{array}{l}\text { Inventory } \\
\text { (I) }\end{array}$ & $\begin{array}{l}\text { Intermediate storage of products, raw } \\
\text { materials, equipment, tools, etc. }\end{array}$ & $\begin{array}{l}\text { - } \quad \text { Queued batches of materials waiting to be used. } \\
\text { - Warehouse/site inventory not translating to sales }\end{array}$ \\
\hline $\begin{array}{l}\text { Defect } \\
\text { (D) }\end{array}$ & $\begin{array}{l}\text { Producing defective work requiring } \\
\text { additional work or generating scrap leading } \\
\text { to a waste of material, manpower and } \\
\text { machine processing time and overall a loss } \\
\text { of production unit. }\end{array}$ & $\begin{array}{l}\text { - } \quad \text { Error in design } \\
\text { - } \quad \text { Error in processing } \\
\text { - } \text { Miscommunication } \\
\text { - Omission }\end{array}$ \\
\hline $\begin{array}{l}\text { Un/Under used } \\
\text { Talent } \\
\text { (UT) }\end{array}$ & $\begin{array}{l}\text { More people involved in the job than } \\
\text { necessary and not leveraging the potential } \\
\text { of workers to the optimum. }\end{array}$ & $\begin{array}{l}\text { - Uneven work distribution } \\
\text { - Unchallenged employees } \\
\text { - Wrong staff to task } \\
\text { - Wasteful admin task }\end{array}$ \\
\hline
\end{tabular}

155 There is considerable research pertaining to quantifying the process waste involved in various 156 traditional onsite construction activities. For instance, Lee et al. (2012) analyzed the waste involved in 157 an onsite steel erection process for a university building, recording 56.93\% NVA activities. Mossman 
158 (2009) also reported 56-65\% NVA, 30-35\% NNVA and only 5-10\% value-adding (VA) activities in

159 the traditional construction process. Similarly, Forsberg and Saukkoriipi (2007) found the average time

160 spent by workers on productive activities in the traditional construction method to be only $30 \%$ of the

161 overall construction time. This form of quantification has not been well addressed for the various OSM

162 methods. A recent study by Zhang et al. (2020) concluded that the lead time is reduced by $20 \%$ from

163 the factory 'stick-built' method of OSM with the introduction of semi-automation in the production

164 line. However, few published studies have analyzed process wastes in the OSM production workflow, 165 particularly between the various OSM methods.

166 Evaluation tools for lean manufacturing and process modeling

167 The need to analyze process waste necessitates an evaluation of the techniques available in practice.

168 There are various tools and techniques used in supporting lean manufacturing. Lean tools can be

169 focused on various aspects, such as waste, inventory, quantity, quality, people, and process controls.

170 However, techniques with objectives of identifying or eliminating process wastes or non-value-adding activities - including value system analysis (VSA) and the 5whys method (Murugaiah et al. 2010) -

172 are used for analyzing processes and identifying sources of waste located throughout the process and

173 are the focus in this study. In order to visualize a process, business process modeling (BPM) tools are

174 used as a means of systematically describing the activities in a process, such as their relationships and

175 information flow: it helps to understand the best way to perform a task by describing its operational performance that produces an output (Nurcan et al. 2005).

177 There are various tools developed for modeling business processes that focus on one or a combination 178 of aspects, such as functional, information, organization, or behavioral aspects in a process. Business 179 Process Mapping Notation (BPMN) is an advanced language due to its more advanced explanatory 180 power. BPMN is clearer and is easier to understand by non-experts since it is similar to a flow chart. 181 There are also industry-specific tools used in manufacturing, e.g., Value Stream Mapping (VSM) as 
an approach to modeling materials and information flow in a production process as the product makes

183 its way through the value stream (Sundar et al. 2014). BPMN is used in this study and some concepts

184 from VSM, such as waste and cycle time, are included in the process model for analysis.

\section{Research method}

186 The study requires an in-depth analysis of processes, which is heavily data reliant. The presence of 187 data silos, typically existing in the context of construction businesses, creates complexity in the 188 modeling processes. Hence, a case study research method is chosen as it is known for its strength in 189 allowing for a holistic in-depth exploration of a subject in its real-life context (Yin 2009). There are 190 two types of case study design: multiple and single case study designs. A single case study involves 191 the use of only one case, while a multiple case study involves a combination of two or more cases that 192 are used to build a theory about a phenomenon (Yin 2016). For this study, a single case study design 193 has been selected to conduct the exploratory research required - the standpoint being that the single 194 case study approach is better for creating high-quality theory, and better when the aim is to shed light 195 on a single setting (Yin 2009).

\section{Data collection and strategy}

197 Understanding a business organization and its operation is challenging as the researchers are detached 198 from the business operation. This is overcome through an exploratory study investigating the 199 production processes closely over a period by first observing the AS-IS process and then with the design and implementation of the TO-BE process. An iterative data collection process is followed, with the use of a wide range of data including observations, information from internal and published 202 documents, interviews with key OSM experts within the case company, and consolidated opinions 203 from focus groups. The purpose of the case is revelatory (Schell 1992), with an embedded single-case research design containing two units of analysis - the production processes of static and semiautomated linear OSM production methods - in order to obtain rich content in place of the breath that 
can be obtained in multiple case design (Sarvimaki 2017). The static method workflow is the AS-IS

207 model (i.e., actual production workflow), while the semi-automated linear method is the TO-BE model

208 (i.e., optimized production model). Figure 1 shows the combination of methods used for data collection

209 and synthesis at different stages of the study.

210 The initial data collection process featured different approaches, starting from a review of technical

211 documents that include the production flow diagram, station design, building design, and organization

212 structure. Also identified is the key information required for analyzing process wastes on the activities

213 performed including their sequences, together with data that could not be collected from documents,

214 i.e., the primary data required for the analysis. For instance, questions were set to identify the 215 quantifiable aspects of each activity, such as delays and waiting, as they cannot be captured directly in

216 the documents. The primary data were then collected through interviews with key experts and

217 observation of production in the factory. The output from this stage is used to develop an initial process

218 model based on the activities performed on the shop floor, and to sketch the shop floor arrangement

219 of production space. BPMN notations and protocols are used to represent the processes.

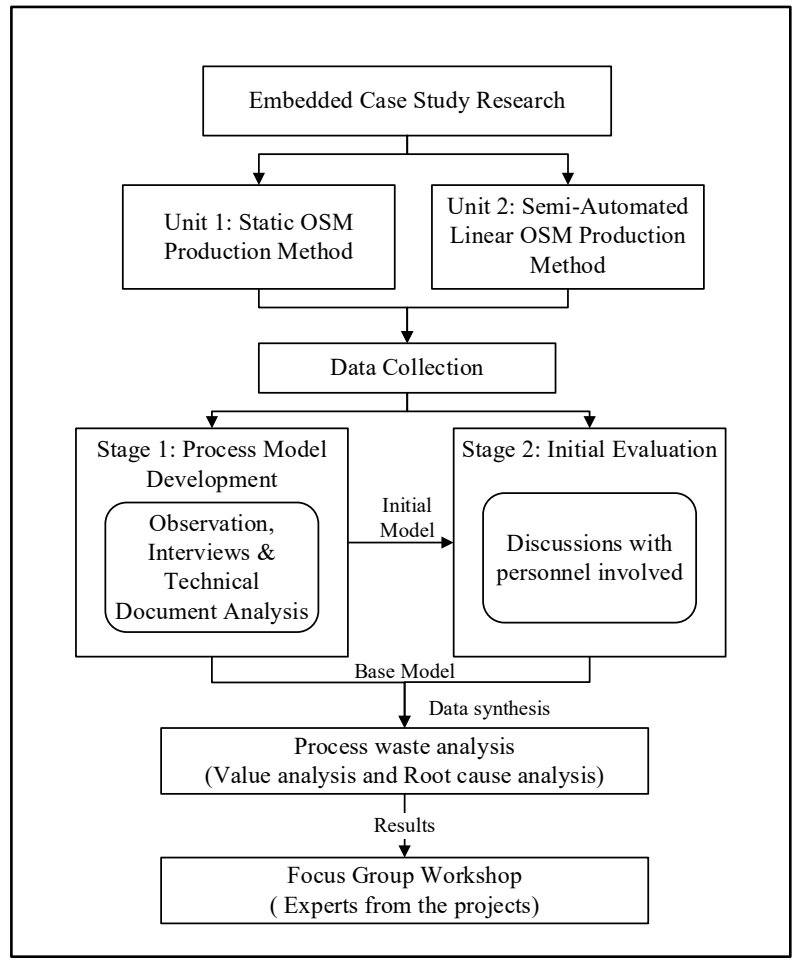

Fig. 1. Research Design 
222 An evaluation of the initial process map was then organized with the parties involved to enable 223 assessment of the model and ensure accurate representation of the activities, sequences, and resource 224 requirements involved. The output from this stage (Stage 1 in Figure 1) provides a base model for 225 analyzing the process waste. The identified lean tools from the review are used for value analysis and 226 waste identification in the process according to the eight categories of process waste: this was used to 227 categorize the activities into VA, NVA, and NNVA, respectively. Finally, a focus group comprising 228 key experts of the existing production (such as the production manager, director for the project, and 229 the commercial manager) was formed to identify the root causes of the waste using the 5 Whys lean 230 tool for root cause (RC) analysis - a questioning method that identifies the root cause through asking 231 the question, 'Why does the issue exist?'.

\section{Case study - Panelised system OSM of light steel frame buildings}

233 The case study is based on one of the largest housing associations located in the UK's West Midlands

234 region (hereafter named HAX). HAX procures social housing using the traditional method through 235 contracting. It has recently recognized the potential for integrating house delivery within the business 236 after internal market research. The business decided to consider OSM as a major delivery approach to 237 align with the new funding body's requirements and the national strategy to adopt Modern Methods 238 of Construction (MMC) as well as to help meet the increased housing delivery target, i.e., $60 \%$ increase 239 of the number of houses delivered per annum. A consortium was formed with a steel manufacturer, an 240 architect production engineer, and a university to develop OSM house products.

241 While there is a need to determine a suitable OSM method to achieve the set objectives, this data is 242 not readily available. During the 2-year study period, HAX used the static method of production for a 243 house prototype to analyze the suitability of the method and the cost involved. Concurrently, an OSM 244 scheme was developed for the production of panels forming the building frame and envelop of the houses using a semi-automated linear method. The semi-automated linear method in the case study is 
246 based on a scheme developed by the production engineer. The scheme incorporates the simulations

247 based on actual production information and detailed workflow incorporating automated stages of sub-

248 assemblies. For instance, the data for the time cycle study is derived from industry-known values for

249 discrete activities. Operator times are based around MTM (Methods-time Measurement) standards

250 while the transfer times are based upon conveyor speeds of 10 meters per min and screw insertion

251 times are based upon trials carried out in previous applications for similar product production. The

252 time cycle study was run with a full sized layout as per the proposed placement of the loading bay and

253 the guarding, buffer station and pallet positions. The cycle time simulation was carried out using the

254 engineer's company template that aggregates the cycle time taking into account the overlapped 255 activities in the production process.

256 The workflows for wall panel production were chosen for a like-to-like comparison between the two 257 methods. Lean manufacturing theory relating to the eight categories of process wastes is applied to 258 analyze the constraints of the two methods and the waste involved to quantify the improvement in the 259 TO-BE method and provide recommendations for CI.

260 Modeling and implementation

\section{Static method OSM production process activities}

262 The static production process of wall panel production as done in a HAX factory is used as a reference 263 for the process modeling: this is an actual (AS-IS) workflow intended to be compared with the 264 simulated workflow. For wall panel production, the key stages are to: 1) assemble the steel frame for 265 wall panels, 2) install the cladding on steel frames, and 3) apply finishes on the cladded steel frames. 266 In the static system, the production is done in silos. Various team members and trade specialists where needed are required to move from one station to another to render services on the panels. The station 268 is arranged such that a team is working on a one-panel type/design while the processes within these stations follow no particular sequence. Also, there is no defined flow of materials or unfinished 
products between the various stations (see Figure 2) and stations sometimes have an individual

271 production plan. Figure 3 illustrates the BPMN process map representing the activities in the static

272 process (one of the stations, as the activities are the same and are repeated for each station), which is

273 a typical push system of manufacturing.

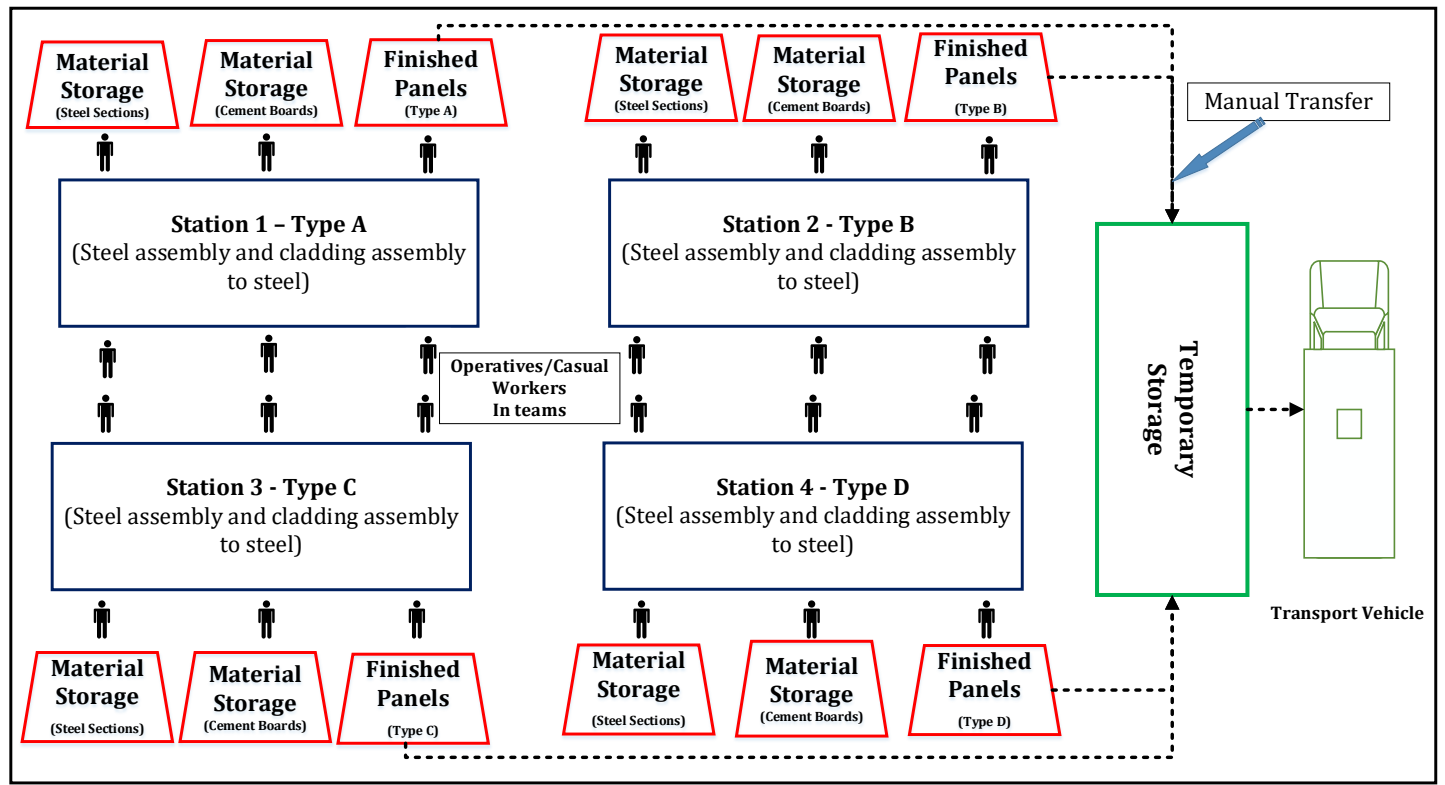

Fig. 2. Static Production Arrangement

276 The overall cycle time involved in a manufacturing process consists of (i) process time (relating to

277 working directly on a product), (ii) waiting time (activities that involve waiting), (iii) loading time 278 (relating to moving materials, partially completed products or completed products) and (iv) inspection 279 time (relating to quality or health and safety). The activities as identified in the process map are 280 classified into three types: value-adding (VA), non-value-adding (NVA), and necessary non-value281 adding (NNVA). For the analysis, the VA activities are activities with a process time, NVA activities 282 involve a waiting and loading time, while NNVAs are activities involving an inspection time.

283 However, the challenge with manual production is that the identified VA activities carried out by 284 operatives may also include some idle time and it is difficult to identify or quantify the embedded waste involved. Hence, some of these may have been missed in the evaluation, which is a limitation. 


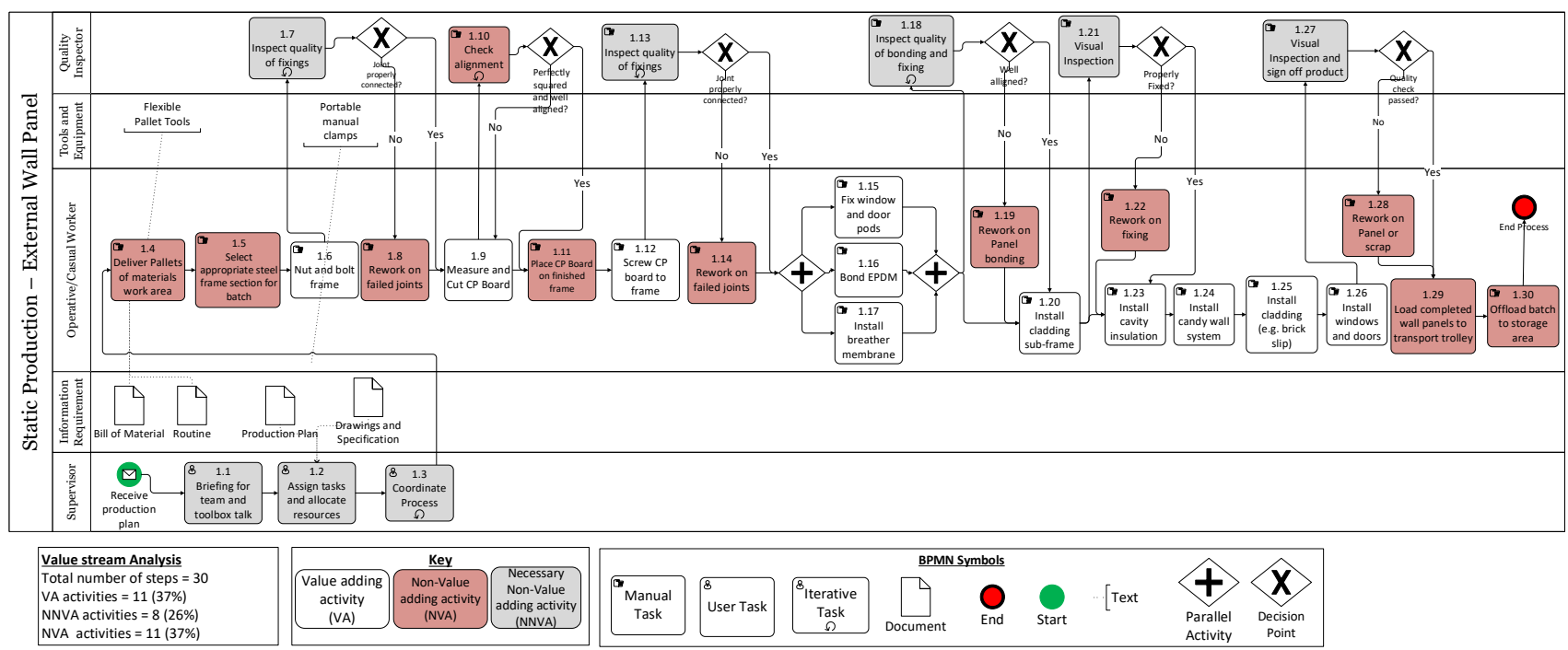

Fig. 3. Production process model for wall panel construction using static method.

290 The cycle time for each activity is modeled using the average time it takes to complete a unit of an 291 offsite product of cladded wall panel for house construction. For each station, the work for a batch is 292 completed by a team of 5 workers: 3 fixers (one is a senior fixer also acting as a supervisor), 1 casual 293 worker, and 1 quality inspector. The activities performed can be categorized into different levels for 294 the purpose of the cycle time estimation, unit or batch level activities. A unit-level activity is required to be carried out on each product while a batch-level activity is performed on a batch of products and the time taken to complete the activity is distributed equally to each unit. Activities 1.1 to $1.5,1.29$, and 1.30 are batch-level activities and the cycle time will be shared by all products from the batch.

298 Other activities are to be performed on every unit of the product; hence, the cycle time recorded in 299 Table 4 is the time taken to complete the activity for each wall panel. Based on observations of the 300 process, the static method has a $15-20 \%$ chance of rework due to minor errors or deviations in the 301 drawings and specifications requirements. That is, for every 10 panels built, there is a chance of 302 additional rectification work being needed on at least 2 panels. Therefore, this assumption is 303 considered when recording the cycle time for rework activities. 
306 Table 3: Process waste analysis in static production method

\begin{tabular}{|c|c|c|c|c|c|c|c|c|c|c|c|c|c|c|}
\hline \multicolumn{3}{|c|}{ Production Station } & \multicolumn{8}{|c|}{ Lean Waste Aspects } & \multicolumn{4}{|c|}{ Time (min) } \\
\hline $\begin{array}{l}\text { Activity } \\
\text { Code }\end{array}$ & Activity & Type & OP & $\mathbf{W}$ & $\mathbf{T}$ & $\mathbf{P}$ & $\mathbf{M}$ & $\mathbf{I}$ & D & UT & $\begin{array}{l}\text { Cycle time } \\
\text { (CT) }\end{array}$ & $\begin{array}{l}\text { VA } \\
\text { Time }\end{array}$ & $\begin{array}{l}\text { NVA } \\
\text { Time }\end{array}$ & NNVA \\
\hline 1.1 & Team briefing & NNVA & & & & & & & & & 1 & - & - & 1 \\
\hline 1.2 & Resource allocation & NNVA & & & & & & & & & 1 & - & - & 1 \\
\hline 1.3 & Process coordination & NNVA & & & & & & & & & - & - & - & - \\
\hline 1.4 & Material delivery & NVA & & $\mathrm{x}$ & $\mathrm{x}$ & & $\mathrm{x}$ & & & & 5 & - & 5 & - \\
\hline 1.5 & $\begin{array}{c}\text { Choosing suitable steel } \\
\text { profile sections }\end{array}$ & NVA & & $\mathrm{x}$ & & & & $\mathrm{x}$ & & & 5 & - & 5 & - \\
\hline 1.6 & Nut and bolt frame & VA & & & & & & & & & 60 & 45 & 15 & - \\
\hline 1.7 & Quality inspection & NNVA & & & & & & & & & 10 & - & 5 & 5 \\
\hline 1.8 & Rework on frames & NVA & & $\mathrm{x}$ & & & & & $\mathrm{x}$ & & 15 & - & 15 & - \\
\hline 1.9 & $\begin{array}{l}\text { Measuring and cutting } \\
\text { cement plasterboard }\end{array}$ & NVA & $\mathrm{x}$ & & & & & & & & 45 & - & 45 & - \\
\hline 1.10 & Check alignment & NVA & $\mathrm{x}$ & & & & & & & & 2 & - & 2 & - \\
\hline 1.11 & Load CP board on frame & NVA & & & & & $\mathrm{x}$ & & & & 10 & - & 10 & - \\
\hline 1.12 & Screw board to frame & VA & & & & & & & & & 40 & 20 & 20 & - \\
\hline 1.13 & $\begin{array}{l}\text { Quality inspection on } \\
\text { fixings }\end{array}$ & NNVA & & $\mathrm{x}$ & & $\mathrm{x}$ & & & & & 10 & - & 5 & 5 \\
\hline 1.14 & Rework on failed joints & NVA & & & & & & & $\mathrm{x}$ & & 15 & - & 15 & - \\
\hline 1.15 & Fix window and door pods & VA & & & & & & & & & 40 & 20 & 20 & - \\
\hline 1.16 & Bond EPDM & VA & & & & & & & & & 40 & 20 & 20 & - \\
\hline 1.17 & Install breather membrane & VA & & & & & & & & & 20 & 15 & 5 & - \\
\hline 1.18 & $\begin{array}{c}\text { Visual inspection on } \\
\text { bonding }\end{array}$ & NNVA & & & & & & & & & 5 & - & - & 5 \\
\hline 1.19 & Rework on bonding & NVA & & & & & & & $\mathrm{x}$ & & 5 & - & 5 & - \\
\hline 1.20 & Install cladding sub-frame & VA & & & & & & & & & 120 & 60 & 60 & - \\
\hline 1.21 & $\begin{array}{l}\text { Visual inspection on sub- } \\
\text { frame fixing }\end{array}$ & NNVA & & & & & & & & & 5 & - & - & 5 \\
\hline 1.22 & Rework & NVA & & & & & & & $\mathrm{x}$ & & 5 & - & 5 & - \\
\hline 1.23 & Install cavity insulation & VA & & & & & & & & & 30 & 20 & 10 & - \\
\hline 1.24 & $\begin{array}{l}\text { Install candy wall system } \\
\text { (backing board) }\end{array}$ & VA & & & & & & & & & 60 & 45 & 15 & - \\
\hline 1.25 & $\begin{array}{l}\text { Install cladding-brick-slip } \\
\text { system }\end{array}$ & VA & & & & & & & & & 60 & 45 & 15 & - \\
\hline 1.26 & Install window and door & VA & & & & & & & & & 80 & 60 & 20 & - \\
\hline 1.27 & $\begin{array}{c}\text { Quality inspection and sign } \\
\text { off }\end{array}$ & NNVA & & $\mathrm{x}$ & & & & & & & 5 & - & - & 5 \\
\hline 1.28 & Rework on defect or scrap & NVA & & & & & & & $\mathrm{x}$ & & 5 & - & 5 & - \\
\hline 1.29 & $\begin{array}{l}\text { Load finished panels to } \\
\text { transport trolley }\end{array}$ & NVA & & & & & $\mathrm{x}$ & & & & 5 & - & 5 & - \\
\hline 1.30 & Load to storage area & NVA & $\mathrm{x}$ & & & & & $\mathrm{x}$ & & & 5 & - & 5 & - \\
\hline \multicolumn{11}{|c|}{ Total Time (Min) } & 709 & 350 & 332 & 27 \\
\hline \multicolumn{11}{|c|}{ Total Time (\%) } & 100 & 49 & 47 & 4 \\
\hline
\end{tabular}

\section{Semi-automated linear method OSM production process activities}

308 In the semi-automated linear method of wall panel production which is based on simulated results as

309 an alternative to the static method, some of the root causes of constraints in the static method are

310 addressed. This method comprises two automated lines for frame and cladding assembly with the use

311 of automated machines and various robotic arms (see Figure 4). Compared to the static method,

312 production is in an assembly line with dedicated stations that allow synchronous flow. Each station

313 has dedicated production team members. Partially completed units are moved in various dedicated 
314 interconnected stages. The units are moved on a conveyor belt and the completed units are picked up

315 by fork-lift trucks to be stored or loaded on transport vehicles. The batch manufacturing method is

316 used, which is a push system. Figure 5 illustrates the BPMN process map representing the activities in

317 the semi-automated linear process of wall panel production.

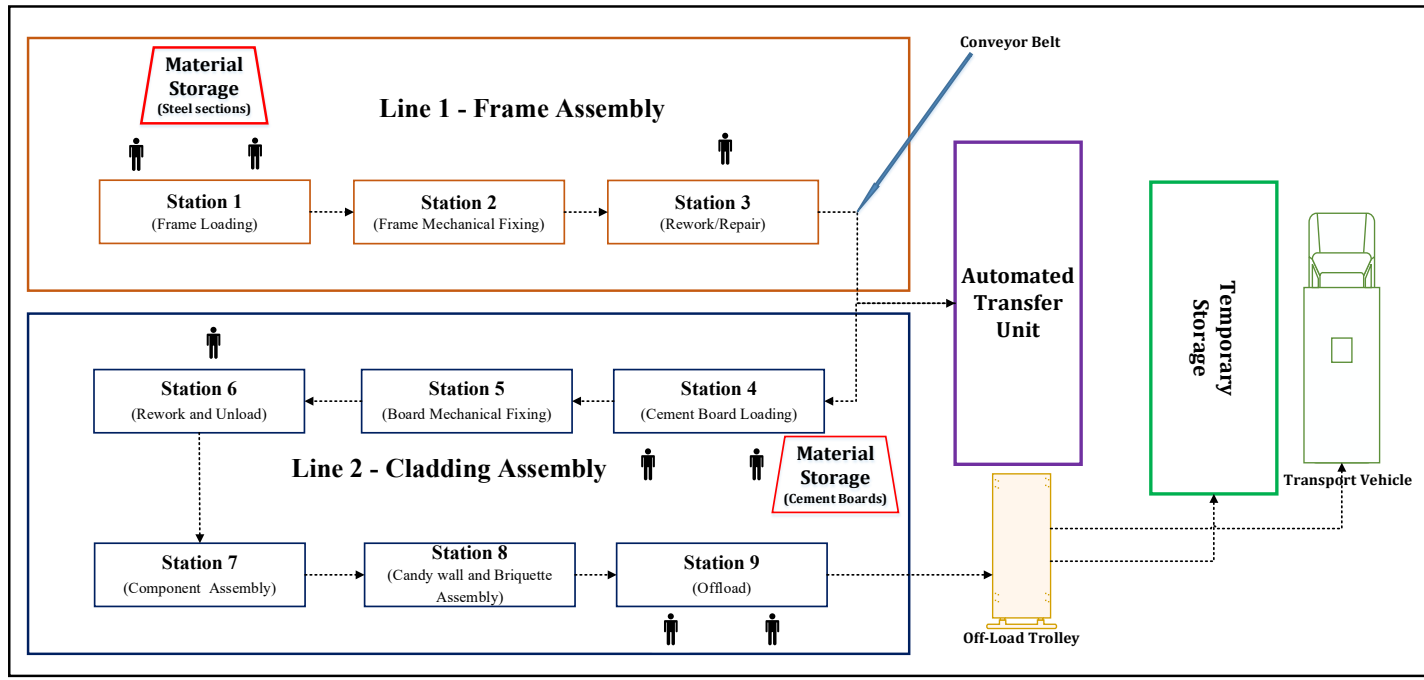

Fig. 4. Semi-automated linear production arrangement

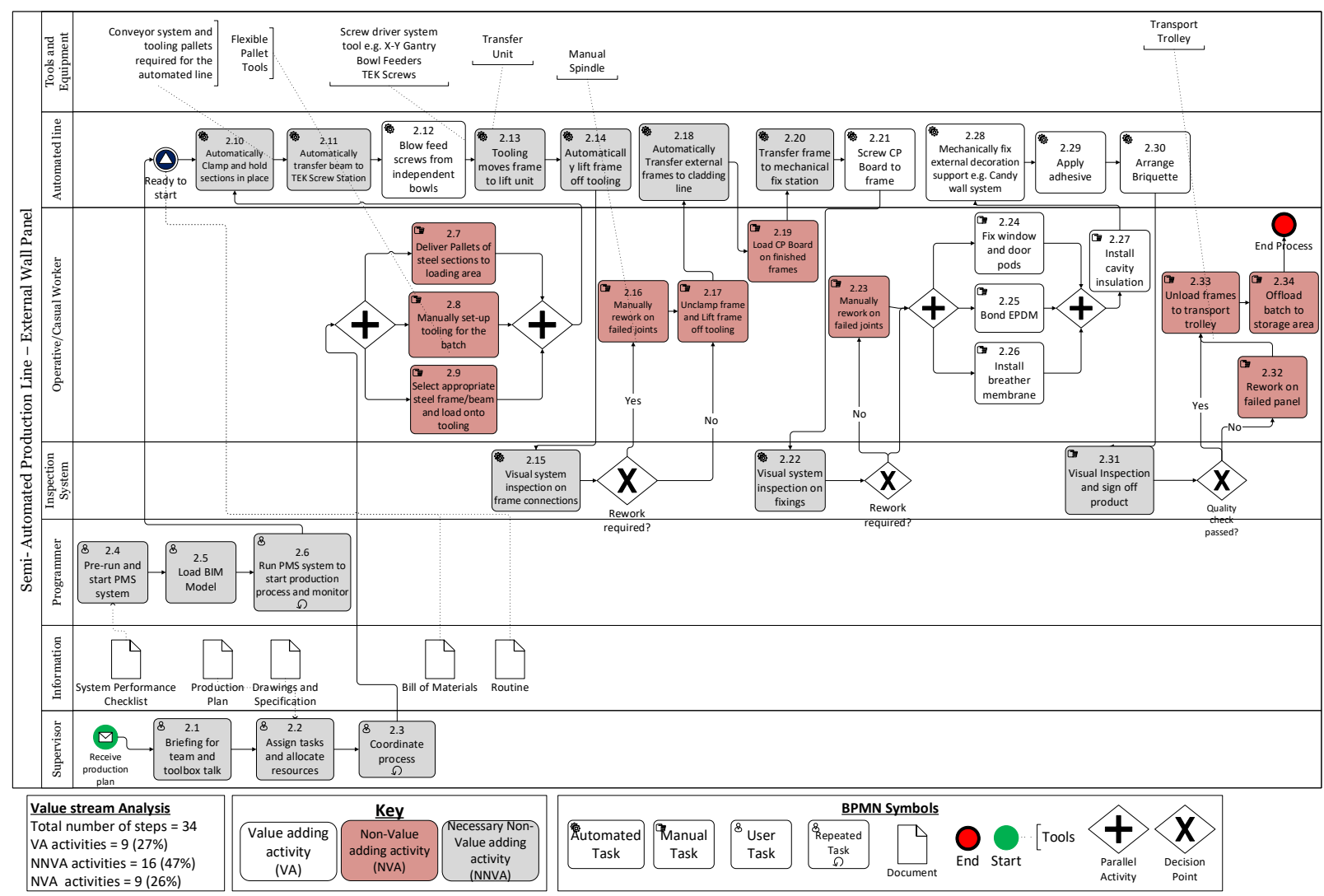

Fig. 5. Production process model for wall panel construction using semi-automated method. 
322 Similar to the method used in analyzing the static process, the cycle time for each activity in the batch

323 manufacturing line is modeled for the new production line using the estimated maximum process time

324 for each activity in every station (Table 4). With this method, the time and waste predictions are based

325 on the production engineers' estimates using the simulated production model according to the

326 workflow arrangement and estimated time of product movement through different stages. The

327 activities contained in the process are also categorized as either unit or batch level activities similar to

328 the static method. In this case, activities 2.1 to 2.9 , then 2.33 and 2.34 are batch-level activities, while

329 others are unit-level activities: hence, the cycle time is shared by the number of units of wall panels

330 produced for the batch.

331 Table 4: Waste analysis in semi-automated production method

\begin{tabular}{|c|c|c|c|c|c|c|c|c|c|c|c|c|c|c|}
\hline \multicolumn{3}{|c|}{ Production Line } & \multicolumn{8}{|c|}{ Waste Aspects } & \multicolumn{4}{|c|}{ Time (min) } \\
\hline $\begin{array}{l}\text { Activity } \\
\text { Code }\end{array}$ & Activity & Type & OP & W & $\mathrm{T}$ & $\mathrm{P}$ & M & I & $\mathrm{D}$ & UT & $\begin{array}{c}\text { Cycle } \\
\text { time } \\
\text { (CT) }\end{array}$ & $\begin{array}{l}\text { VA } \\
\text { Time }\end{array}$ & $\begin{array}{l}\text { NVA } \\
\text { Time }\end{array}$ & $\begin{array}{l}\text { NNVA } \\
\text { Time }\end{array}$ \\
\hline 2.1 & Team briefing & NNVA & & & & & & & & & 1 & - & - & 1 \\
\hline 2.2 & Resource allocation & NNVA & & & & & & & & & 1 & - & - & 1 \\
\hline 2.3 & Process coordination & NNVA & & & & & & & & & - & - & - & - \\
\hline 2.4 & Pre-run PMS system & NNVA & & & & & & & & & 2 & - & - & 2 \\
\hline 2.5 & Load BIM model & NNVA & & & & & & & & & 2 & - & - & 2 \\
\hline 2.6 & Monitor system & NNVA & & & & & & & & & 5 & - & - & 5 \\
\hline 2.7 & Material delivery & NVA & & $\mathrm{x}$ & $\mathrm{x}$ & & $\mathrm{x}$ & & & & 5 & - & 5 & - \\
\hline 2.8 & Tool set-up for batch & NVA & & $\mathrm{x}$ & & & & & & & 2 & - & 2 & - \\
\hline 2.9 & $\begin{array}{l}\text { Choosing suitable steel } \\
\text { profile sections }\end{array}$ & NVA & & $\mathrm{x}$ & & & & & & & 5 & - & 5 & - \\
\hline 2.10 & Clamp section in place & NNVA & & & & & & & & & 0.5 & - & - & 0.5 \\
\hline 2.11 & Transfer to screw station & NNVA & & & & & & & & & 0.5 & - & - & 0.5 \\
\hline 2.12 & Screw frame on both side & VA & & & & & & & & & 6.78 & 6.78 & - & - \\
\hline 2.13 & Tooling return & NNVA & & & & & & & & & 0.5 & - & - & 0.5 \\
\hline 2.14 & Lift frame off tooling & NNVA & & & & & & & & & 1 & - & - & 1 \\
\hline 2.15 & $\begin{array}{c}\text { Visual inspection by } \\
\text { system }\end{array}$ & NNVA & & & & & & & & & 1 & - & - & 1 \\
\hline 2.16 & Rework on failed joints & NVA & & & & & & & $\mathrm{x}$ & & 5 & - & 5 & - \\
\hline 2.17 & $\begin{array}{l}\text { Unload frame from } \\
\text { tooling }\end{array}$ & NNVA & & $\mathrm{x}$ & & & & & & & 2 & - & 2 & - \\
\hline 2.18 & $\begin{array}{l}\text { Transfer frame to } \\
\text { cladding line }\end{array}$ & NNVA & & & & & & & & & 0.5 & - & - & 0.5 \\
\hline 2.19 & Load CP board & NVA & & $\mathrm{x}$ & & & & & & & 5 & - & 5 & - \\
\hline 2.20 & $\begin{array}{l}\text { Transfer frame for } \\
\text { mechanical fixing }\end{array}$ & NNVA & & & & & & & & & 0.5 & - & 0.5 & - \\
\hline 2.21 & Screw CP board to frame & VA & & & & & & & & & 6.78 & 6.78 & - & - \\
\hline 2.22 & $\begin{array}{c}\text { Visual inspection by } \\
\text { system }\end{array}$ & NNVA & & & & & & & & & 1 & 1 & - & - \\
\hline 2.23 & Rework on failed joints & NVA & & & & & & & & $\mathrm{x}$ & 5 & - & 5 & - \\
\hline 2.24 & Fix window and door pod & VA & & & & & & & & & 40 & 35 & 5 & - \\
\hline 2.25 & Bond EPDM & VA & & & & & & & & & 20 & 20 & - & - \\
\hline 2.26 & Install breather membrane & VA & & & & & & & & & 20 & 15 & 5 & - \\
\hline 2.27 & Install cavity insulation & VA & & & & & & & & & 20 & 20 & - & - \\
\hline 2.28 & $\begin{array}{c}\text { Fix external decoration } \\
\text { support }\end{array}$ & VA & & & & & & & & & 6.78 & 6.78 & - & - \\
\hline 2.29 & Apply adhesive & VA & & & & & & & & & 5 & 5 & - & - \\
\hline 2.30 & Arrange briquette & VA & & & & & & & & & 10 & 10 & - & - \\
\hline 2.31 & $\begin{array}{l}\text { Visual inspection and sign } \\
\text { off product }\end{array}$ & NNVA & & & & & & & & & 5 & - & - & 5 \\
\hline 2.32 & Rework on failed panel & NVA & & & & & & & & $\mathrm{x}$ & 5 & - & 5 & - \\
\hline 2.33 & Unload frames to trolley & NVA & & & & $\mathrm{x}$ & $\mathrm{x}$ & & & & 5 & - & 5 & - \\
\hline
\end{tabular}




\begin{tabular}{|c|c|c|c|c|c|c|c|c|}
\hline 2.34 & $\begin{array}{l}\text { Offload batch to storage } \\
\text { area }\end{array}$ & NVA & $\mathrm{x}$ & & 5 & - & 5 & - \\
\hline \multicolumn{5}{|r|}{ Total Time (Min) } & 201 & 126 & 54 & 21 \\
\hline \multicolumn{5}{|r|}{ Total Time (\%) } & 100 & 63 & 27 & 10 \\
\hline
\end{tabular}

\section{Discussion}

334 The process analysis of the two methods of OSM production revealed some data on the differences in

335 the units of analysis. A summary of the results of the comparison of both OSM methods is provided

336 in Figures 6 and 7. Based on Figure 3, for the static method, the total number of activities required to

337 produce a unit of wall panel is 30 , with $37 \%$ of these activities being non-value-adding (NVA). In

338 contrast, the semi-automated method automates some of the key activities and introduces additional

339 steps to enable a structured workflow. This method contains 34 activities in total, of which $26 \%$ are

340 non-value-adding activities (NVA) since some human intervention is eliminated, which is an

341 approximately $30 \%$ decrease in NVA activities compared to the static method (Figure 6).

\section{Proportion of Activities (\%)}

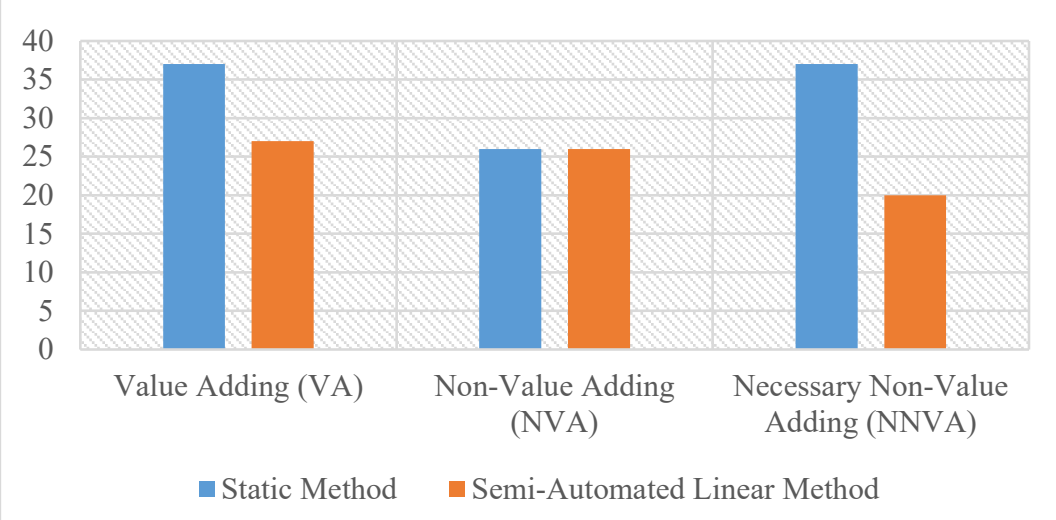

Fig. 6. Comparison of proportion of activities performed for wall panel production. 


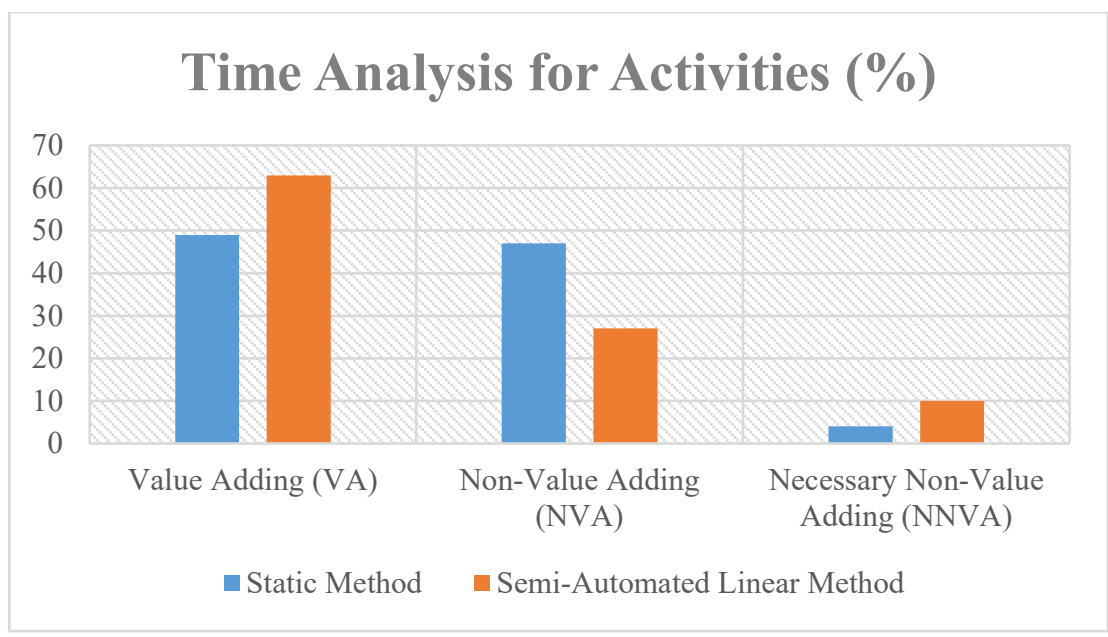

Fig. 7. Comparison of time taken for activities performed for wall panel production.

346 In terms of process time analysis, only $49 \%$ of the actual time spent in the production workflow is 347 value-adding time in the static method (Figure 7), which is at a similar rate to the onsite methods 348 reported in past literature, i.e., up to 50\% non-value-added activities (Liu et al. 2011, Nikakhtar et al. 349 2015). This implies that there is little improvement to the static method of production in terms of 350 reduced process waste, which supports the criticism by Zhang et al. (2020) that some factory house 351 building methods simply replicate onsite construction inefficiencies. In contrast, in the semi-automated 352 method, the use of robotic arms for the fabrication of the steel frame for wall panels significantly 353 reduces the time required to manually assemble steel members. Therefore, the semi-automated method 354 reported improved productivity with the VA time of $63 \%$ compared to $49 \%$ in the static method, which 355 is an increase of approximately $29 \%$ in the VA time. Also, it takes 201 minutes of overall lead time 356 (total time required from the first to the last workstation) to produce a single unit wall panel in the 357 semi-automated method, with 126 minutes of value-added time (actual process time). In contrast, the 358 static method takes 709 minutes based on the workflow to complete the processing of a unit wall panel, 359 with only 350 minutes of value-added time. This implies that the semi-automated method provides a $36070 \%$ reduction in the lead time from the static method, which is significantly greater than the $20 \%$ reported by Zhang et al. (2020). The variance can be explained as a result of the production line design, workflow arrangement and level of automation involved, as no two manufacturers incorporate the 
exact same process since the manufacturing environment offers different options for producing the 364 same product.

365 Upon further analysis of the root cause (RC) of the waste generated with the static method, some 366 constraints in the processes are revealed as detailed in Table 5. In terms of process waste resulting 367 from waiting (W) and movement (M), factory/workstation arrangement and inefficient process flow were reported as the $\mathrm{RC}$ of the issues in the static method of production. The ad-hoc nature of activities led to a non-guaranteed cycle time for each activity, as no standardized sequence was adopted. Although activities relating to Quality Inspection (QI) are classified as NNVA, QI is major source of delay in the static method due to operatives waiting for inspections to be completed in order to move to the next step. Although QI is highly important for avoiding scrapping finished panels due to defects,

373 it is observed that this causes over-processing waste $(\mathrm{P})$ because of the excessive number of 374 intermediate inspections incorporated in the process which, as seen in the semi-automated method, 375 could be reduced with better efficiency enabled with the help of automation. For instance, the use of a 376 manufacturing line with dedicated stages improves the workstation arrangement and flow as a result.

377 A visual inspection system displaying the position of fault screws was included in the semi-automated method manufacturing line, which enables the operators stationed in the rework station to quickly rectify faults. This system was introduced after the analysis of the RC in the static method and results in the elimination of some waste relating to waiting and movement in the static method.

381 Another major waste in the static method is due to the frequent rework required in the process, where 382 the chances of process waste due to defects, thus resulting in rework, is around $15-20 \%$. In contrast, 383 the need for rework is projected to be below $5 \%$ with the semi-automated method due to the efficiency 384 of the robotic arm used for key activities (e.g., screwing and fixing) that are prone to error. The 5\% 385 rework is mainly due to some value-adding manual activities e.g., bonding the breather membrane.

Table 5: Root cause (RC) analysis for static production method NVA activities 


\begin{tabular}{|c|c|c|c|c|c|c|c|c|}
\hline \multicolumn{2}{|c|}{ Production Line } & \multirow[t]{2}{*}{ Waste } & \multirow{2}{*}{$\begin{array}{c}\text { Issue/ } \\
\text { Symptom }\end{array}$} & \multicolumn{5}{|c|}{ 5Whys of lean } \\
\hline $\begin{array}{l}\text { Activity } \\
\text { Code }\end{array}$ & Activity & & & Why 1 & Why 2 & Why 3 & Why 4 & $\begin{array}{c}\text { Why } 5 \\
(R C)\end{array}$ \\
\hline \multirow[t]{2}{*}{1.4} & \multirow[t]{2}{*}{$\begin{array}{l}\text { Material } \\
\text { delivery }\end{array}$} & Waiting & $\begin{array}{l}\text { Operatives waiting for } \\
\text { stock on production line. }\end{array}$ & $\begin{array}{l}\text { Needs to be } \\
\text { moved from } \\
\text { store to } \\
\text { production } \\
\text { area }\end{array}$ & $\begin{array}{l}\text { Inventory } \\
\text { checks need to } \\
\text { be carried out }\end{array}$ & $\begin{array}{l}\text { Process too } \\
\text { slow, causing } \\
\text { impact on } \\
\text { production } \\
\text { flow }\end{array}$ & $\begin{array}{l}\text { Variable task } \\
\text { duration }\end{array}$ & $\begin{array}{l}\text { Inefficient } \\
\text { process flow } \\
\text { design }\end{array}$ \\
\hline & & $\begin{array}{l}\text { Movement } \\
\text { and } \\
\text { transportation }\end{array}$ & $\begin{array}{l}\text { Moving and transporting } \\
\text { materials from store to } \\
\text { production area }\end{array}$ & $\begin{array}{l}\text { Moving } \\
\text { materials from } \\
\text { storage }\end{array}$ & $\begin{array}{l}\text { Storage not } \\
\text { close to } \\
\text { production line }\end{array}$ & $\begin{array}{l}\text { Space } \\
\text { management }\end{array}$ & $\begin{array}{l}\text { Factory } \\
\text { arrangement }\end{array}$ & $\begin{array}{l}\text { Inefficient } \\
\text { factory } \\
\text { arrangement }\end{array}$ \\
\hline \multirow[t]{2}{*}{1.5} & \multirow{2}{*}{$\begin{array}{l}\text { Choosing } \\
\text { suitable } \\
\text { steel } \\
\text { profile } \\
\text { sections }\end{array}$} & Waiting & $\begin{array}{l}\text { Operatives sorting } \\
\text { appropriate frames from } \\
\text { material batch }\end{array}$ & $\begin{array}{l}\text { Variable task } \\
\text { duration }\end{array}$ & $\begin{array}{l}\text { Non-balanced } \\
\text { line }\end{array}$ & $\begin{array}{l}\text { Non-balanced } \\
\text { flow }\end{array}$ & $\begin{array}{l}\text { Ill-designed } \\
\text { space to pick } \\
\text { and store } \\
\text { frames }\end{array}$ & $\begin{array}{l}\text { Inefficient } \\
\text { workstation }\end{array}$ \\
\hline & & Inventory & $\begin{array}{l}\text { Batches of materials } \\
\text { waiting to be processed }\end{array}$ & $\begin{array}{l}\text { Inventory } \\
\text { needs to be } \\
\text { completed }\end{array}$ & $\begin{array}{l}\text { To ensure } \\
\text { correct } \\
\text { materials are } \\
\text { being chosen }\end{array}$ & $\begin{array}{l}\text { Ensure } \\
\text { specifications } \\
\text { are being } \\
\text { followed }\end{array}$ & $\begin{array}{l}\text { Correct } \\
\text { drawings in } \\
\text { place }\end{array}$ & $\begin{array}{l}\text { Problem from } \\
\text { the push } \\
\text { production } \\
\text { method }\end{array}$ \\
\hline \multirow[t]{2}{*}{1.8} & \multirow[t]{2}{*}{$\begin{array}{l}\text { Rework on } \\
\text { frames }\end{array}$} & Waiting & $\begin{array}{l}\text { Waiting for quality } \\
\text { inspection to be } \\
\text { completed, which slows } \\
\text { down following process }\end{array}$ & $\begin{array}{l}\text { Not enough } \\
\text { QI inspectors } \\
\text { to meet } \\
\text { production } \\
\text { flow }\end{array}$ & $\begin{array}{l}\text { Bottleneck in } \\
\text { production } \\
\text { flow }\end{array}$ & $\begin{array}{l}\text { Bottleneck in } \\
\text { production } \\
\text { flow }\end{array}$ & $\begin{array}{l}\text { Trades not } \\
\text { being used to } \\
\text { full capacity } \\
\text { during shifts }\end{array}$ & $\begin{array}{l}\text { Lack of } \\
\text { investment in } \\
\text { automated } \\
\text { inspection } \\
\text { systems }\end{array}$ \\
\hline & & Defect & $\begin{array}{l}\text { Frame joints not properly } \\
\text { connected }\end{array}$ & $\begin{array}{l}\text { Human error } \\
\text { from } \\
\text { operatives } \\
\text { such as } \\
\text { omission }\end{array}$ & $\begin{array}{l}\text { Delay in target } \\
\text { which causes } \\
\text { work to be } \\
\text { rushed }\end{array}$ & $\begin{array}{l}\text { Time } \\
\text { constraints to } \\
\text { meet customer } \\
\text { demands }\end{array}$ & $\begin{array}{l}\text { Delay and } \\
\text { waiting in the } \\
\text { process, such } \\
\text { as stage sign } \\
\text { off by Q1 }\end{array}$ & $\begin{array}{l}\text { Inefficient flow } \\
\text { of production } \\
\text { with many } \\
\text { delays }\end{array}$ \\
\hline 1.9 & $\begin{array}{l}\text { Measuring } \\
\text { and cutting } \\
\text { CP Board }\end{array}$ & $\begin{array}{c}\text { Over- } \\
\text { processing }\end{array}$ & $\begin{array}{l}\text { Extra processing on } \\
\text { cement board before } \\
\text { being used. }\end{array}$ & $\begin{array}{l}\text { Cement board } \\
\text { not pre-cut } \\
\text { from supplier }\end{array}$ & $\begin{array}{l}\text { Process is slow } \\
\text { due to dust } \\
\text { generation }\end{array}$ & $\begin{array}{l}\text { Process not } \\
\text { automated for } \\
\text { machine cut }\end{array}$ & $\begin{array}{l}\text { Process not } \\
\text { automated for } \\
\text { machine cut }\end{array}$ & $\begin{array}{l}\text { Process not } \\
\text { automated for } \\
\text { machine cut }\end{array}$ \\
\hline \multirow[t]{2}{*}{1.10} & \multirow[t]{2}{*}{$\begin{array}{l}\text { Check } \\
\text { alignment }\end{array}$} & $\begin{array}{c}\text { Over- } \\
\text { processing }\end{array}$ & $\begin{array}{l}\text { Too many quality checks } \\
\text { that could be avoided }\end{array}$ & $\begin{array}{l}\text { Human error } \\
\text { from } \\
\text { operatives }\end{array}$ & $\begin{array}{l}\text { Inexperienced } \\
\text { trades carrying } \\
\text { out the works }\end{array}$ & $\begin{array}{l}\text { Re-skilling of } \\
\text { workforce not } \\
\text { adequately } \\
\text { invested in }\end{array}$ & $\begin{array}{l}\text { Lack of } \\
\text { investment in } \\
\text { people and } \\
\text { skills training }\end{array}$ & $\begin{array}{l}\text { Lack of } \\
\text { investment in } \\
\text { people and } \\
\text { skills training }\end{array}$ \\
\hline & & Waiting & $\begin{array}{l}\text { Operatives having to } \\
\text { wait for checks to be } \\
\text { completed to execute } \\
\text { next process }\end{array}$ & $\begin{array}{l}\text { QI inspection } \\
\text { process too } \\
\text { slow }\end{array}$ & $\begin{array}{l}\text { Quality } \\
\text { inspector } \\
\text { working on } \\
\text { other jobs }\end{array}$ & $\begin{array}{l}\text { Operatives not } \\
\text { skilled to self- } \\
\text { check }\end{array}$ & $\begin{array}{l}\text { Lack of } \\
\text { investment in } \\
\text { automated } \\
\text { inspection } \\
\text { systems }\end{array}$ & $\begin{array}{l}\text { Lack of } \\
\text { investment in } \\
\text { automated } \\
\text { inspection } \\
\text { systems }\end{array}$ \\
\hline 1.11 & $\begin{array}{l}\text { Load } \\
\text { cement } \\
\text { board on } \\
\text { frame }\end{array}$ & Movement & $\begin{array}{l}\text { Operatives moving from } \\
\text { material storage to line. }\end{array}$ & $\begin{array}{l}\text { Fork-lift truck } \\
\text { not available }\end{array}$ & $\begin{array}{l}\text { Not enough } \\
\text { CAPEX } \\
\text { invested for } \\
\text { more than one } \\
\text { fork-lift truck }\end{array}$ & $\begin{array}{l}\text { Not forecasted } \\
\text { correctly with } \\
\text { new orders }\end{array}$ & $\begin{array}{l}\text { Lack of } \\
\text { understanding } \\
\text { of supply \& } \\
\text { demand }\end{array}$ & $\begin{array}{l}\text { Lack of } \\
\text { understanding } \\
\text { of supply \& } \\
\text { demand }\end{array}$ \\
\hline 1.14 & $\begin{array}{l}\text { Rework on } \\
\text { joints }\end{array}$ & Defect & $\begin{array}{l}\text { Wall joints not properly } \\
\text { connected }\end{array}$ & $\begin{array}{l}\text { Rushed work } \\
\text { and quality of } \\
\text { installation } \\
\text { inadequate }\end{array}$ & $\begin{array}{l}\text { Too much of a } \\
\text { backlog }\end{array}$ & $\begin{array}{l}\text { Work shifts not } \\
\text { planned } \\
\text { correctly }\end{array}$ & $\begin{array}{l}\text { Work not } \\
\text { planned } \\
\text { correctly }\end{array}$ & $\begin{array}{l}\text { Inefficient } \\
\text { process flow } \\
\text { design }\end{array}$ \\
\hline 1.19 & $\begin{array}{l}\text { Rework on } \\
\text { joints }\end{array}$ & Defect & $\begin{array}{l}\text { EPDM and window } \\
\text { joints not properly fixed }\end{array}$ & $\begin{array}{l}\text { Rushed and } \\
\text { quality of } \\
\text { installation } \\
\text { inadequate }\end{array}$ & $\begin{array}{l}\text { Too much of a } \\
\text { backlog with } \\
\text { too many } \\
\text { defects }\end{array}$ & $\begin{array}{l}\text { Not enough } \\
\text { skilled } \\
\text { workforce }\end{array}$ & $\begin{array}{l}\text { Lack of } \\
\text { investment in } \\
\text { people and } \\
\text { skills training }\end{array}$ & $\begin{array}{l}\text { Lack of } \\
\text { investment in } \\
\text { people and } \\
\text { skills training }\end{array}$ \\
\hline 1.22 & $\begin{array}{l}\text { Rework on } \\
\text { sub frame }\end{array}$ & Defect & $\begin{array}{l}\text { Sub-frame not properly } \\
\text { fixed }\end{array}$ & $\begin{array}{l}\text { Too many } \\
\text { mistakes in } \\
\text { joint fixings }\end{array}$ & $\begin{array}{l}\text { Rushed work } \\
\text { and quality of } \\
\text { installation } \\
\text { inadequate }\end{array}$ & $\begin{array}{l}\text { Too much of a } \\
\text { backlog }\end{array}$ & $\begin{array}{l}\text { Work shifts not } \\
\text { planned } \\
\text { correctly }\end{array}$ & $\begin{array}{l}\text { Inefficient } \\
\text { process flow } \\
\text { design }\end{array}$ \\
\hline 1.28 & $\begin{array}{l}\text { Final } \\
\text { rework on } \\
\text { defect wall }\end{array}$ & Defect & $\begin{array}{l}\text { Panel did not pass } \\
\text { quality checklist }\end{array}$ & $\begin{array}{l}\text { Rushed work } \\
\text { and quality of } \\
\text { installation } \\
\text { inadequate }\end{array}$ & $\begin{array}{l}\text { Sequencing } \\
\text { broken down } \\
\text { due to too } \\
\text { many defects in } \\
\text { previous panels }\end{array}$ & $\begin{array}{l}\text { Too much of a } \\
\text { backlog with } \\
\text { too many } \\
\text { defects }\end{array}$ & $\begin{array}{l}\text { Not enough } \\
\text { skilled } \\
\text { workforce }\end{array}$ & $\begin{array}{l}\text { Lack of } \\
\text { investment in } \\
\text { people and } \\
\text { skills training }\end{array}$ \\
\hline 1.29 & $\begin{array}{l}\text { Load } \\
\text { finished } \\
\text { panels to } \\
\text { transport } \\
\text { trolley }\end{array}$ & Movement & $\begin{array}{l}\text { The need to move } \\
\text { completed batch from } \\
\text { work area }\end{array}$ & $\begin{array}{l}\text { Movement of } \\
\text { workers in the } \\
\text { factory }\end{array}$ & $\begin{array}{l}\text { Large amount } \\
\text { of work in } \\
\text { progress (WIP) }\end{array}$ & Overproduction & Overproduction & Overproduction \\
\hline 1.30 & $\begin{array}{l}\text { Transport } \\
\text { and load } \\
\text { finished } \\
\text { panels to } \\
\text { storage }\end{array}$ & Transportation & $\begin{array}{l}\text { Movement of finished } \\
\text { panels to storage area } \\
\text { because not ready to } \\
\text { deliver to site }\end{array}$ & $\begin{array}{l}\text { Not due to } \\
\text { arrive onsite }\end{array}$ & Overproduction & $\begin{array}{l}\text { Push } \\
\text { manufacturing } \\
\text { system }\end{array}$ & $\begin{array}{l}\text { Push } \\
\text { manufacturing } \\
\text { system }\end{array}$ & $\begin{array}{l}\text { Push } \\
\text { manufacturing } \\
\text { system }\end{array}$ \\
\hline
\end{tabular}

387 Nonetheless, although the semi-automated method helped eliminate some of the process waste in the

388 static method, some process waste relating to inventory (I) is similar in both methods due to the batch 
production system adopted. This method of production causes inventory to build up: thus a storage

390 area is needed in the factory to stack the work-in-progress (WIP) panels until they are ready to be

391 moved to the site - resulting in an additional estimated waiting time of between 4-5 days in the static

392 method. This would consequently result in an added cost for a single unit of the product and perhaps

393 increase the cost of offsite production. There is a need to consider and implement other lean practices

394 targeted at preventing waste due to inventory in the manufacturing process to increase the

395 competitiveness of OSM houses as compared to houses built onsite.

\section{Conclusion}

397 The case study presents a systematic analysis of two offsite house building methods using two lean 398 tools of value system analysis and RC analysis. The efficiency of the production process of a wall 399 panel in terms of the eight process waste types is analyzed. The result from the study reveals that up 400 to $47 \%$ NVA time is spent in the production process in the static method involving non-structured 401 workflow, and a potential to reduce this to $27 \%$ with the semi-automated method of production. From 402 the case analyzed, it is revealed that the overall lead time taken to produce a unit wall panel (in the 403 static method) can be reduced to up to $70 \%$ with a more structured workflow and the automation of 404 critical activities in the process (using the semi-automated method). It is concluded, therefore, that the 405 static method may not provide significant improvement in process waste when compared to the onsite 406 production method based on the quantification results from previous studies. Similar unstructured 407 processes are used in both methods, leading to the repetition of such constraints with the onsite method 408 in factory production as wastes relating to waiting, movements, and defects. Thus, moving construction 409 to a factory environment does not necessarily provide the leanness desired, unless approaches to lean 410 manufacturing are incorporated (such as a structured workflow flow, repetition, and automation).

411 This study is based on a case study of a specific production line design and workflow, only an 412 analytical generalization (Hyde 2000) can be achieved, e.g. based on the degree of similarity between 
413 the two similar contexts, such as offsite manufactured products with similar production to the steel

414 framed panel in this case. In addition, while the study is based on only one OSM system, i.e., a

415 panelized system, similar processes and constraints are likely to be present in other OSM systems such

416 as volumetric or hybrid methods.

417 The study presents quantitative evidence of the performance of structured and non-structured OSM 418 methods in terms of eliminating process waste. The implication of the result is the need for offsite

419 manufacturers to take a process view of their production approach, recognizing the impact of 420 automating critical activities and the importance of incorporating structured workflow and repetition 421 to support mass customization. This paper also documents a simple approach that can be adapted to 422 analyze other production methods and OSM processes to support decision-making relating to the 423 choice of OSM methods.

\section{Data Availability Statement}

425 The data used in this study to support the findings such as the production line design, simulated 426 production line process data and the wall panel design were provided by third parties and the industry 427 partners working on innovate UK funded project No. 104798 and are confidential in nature. The data 428 may only be provided with restrictions.

\section{Acknowledgment}

430 This research was supported by an Innovate UK funded project (Project no.104798) "Collaborative 431 Knowledge-Based DfMA approach to building cost-efficient, low impact, and high-performance 432 houses". Many thanks are due to the participating industrial partners of the research project, 433 particularly Mr. Paul Nicol and Mr. Tim O’Shea of the WHG group, Mr. Ben Towe of the Hadley 434 Group, Mr. Jason Glasse of QM systems, and Mr. Ged Connor of Northmill Architects for their 435 contribution in this study. 


\section{References}

437 Aguilar-Savén, R.S., 2004. Business process modelling: Review and framework. International Journal of Production Economics, 90 (2), 129-149.

439 Akasah, Z.A., Amirudin, R., and Alias, M., 2010. Maintenance management process model for school 440 buildings: An application of IDEF 0 modelling methodology. Australian Journal of Civil $441 \quad$ Engineering, $8(1), 1-12$.

Arif, M. and Egbu, C., 2010. Making a case for offsite construction in Making a case for offsite construction in China. Engineering Construction \& Architectural Management, 17 (6), 536-548.

444 Ayinla, K.O., Cheung, F., and Tawil, A.R., 2019. Demystifying the concept of offsite manufacturing method: Towards a robust definition and classification system. Construction Innovation, 20 (2), $223-246$.

Barber, K.D., Dewhurst, F.W., Burns, R.L.D.H., and Rogers, J.B.B., 2003. Business-process modelling and simulation for manufacturing management: A practical way forward. Business Process Management Journal, 9 (4), 527-542.

Bertelsen, S., 2005. Modularization - a third approach to making construction lean? In: 13th annual conference in the International Group for Lean Construction. Sydney, Australia, 1-11.

Blismas, N., Pasquire, C., and Gibb, A., 2006. Bene t evaluation for o ff-site production in construction. Construction Management \& Economics, 24 (2), 121-130.

454 Cheung, F.K.T., Kurul, E., and Oti, A.H., 2016. A case study of hybrid strategies to create value for a contracting business in the education sector in England and Wales. Construction Management and Economics, 34 (4-5), 335-352.

Dave, B., Koskela, L., and Kiviniemi, A., 2013. Implementing Lean in construction: Lean construction 458 and BIM. CIRIA Guide C725 - Construction Industry Research and Information Association. 
460 Doomun, R. and Jungum, N.V., 2008. Business process modelling, simulation and reengineering: Call centres. Business Process Management Journal, 14 (6), 838-848.

Eastman, C.M. and Sacks, R., 2008. Relative Productivity in the AEC Industries in the United States for On-Site and Off-Site Activities. Journal of Construction Engineering and Management, 134 (7), 517-526.

Fernández-solís, J.L., 2009. How the Construction Industry does differ from manufacturing? In: Associated Schools of Construction International Proceedings of the 45th Annual Conference. Gainesville.

Forsberg, A. and Saukkoriipi, L., 2007. Measurement of waste and productivity in relation to lean thinking. In: Lean Construction: A New Paradigm for Managing Capital Projects - 15th IGLC Conference. 67-76.

Gbadamosi, A.Q., Mahamadu, A.M., Oyedele, L.O., Akinade, O.O., Manu, P., Mahdjoubi, L., and Aigbavboa, C., 2019. Offsite construction: Developing a BIM-Based optimizer for assembly. Journal of Cleaner Production, 215, 1180-1190.

Gibb, A.G.F., 1999. Off-site fabrication: Prefabrication, Pre-assembly and Modularisation. New York: John Wiley \& Sons.

Gibb, A.G.F. and Isack, F., 2003. Re-engineering through pre-assembly: client expectations and drivers. Building Research \& Information, 31 (2), 146-160.

Gorgolewski, M.T., 2005. The Potential for Prefabrication in UK Housing to Improve Sustainability. In: J. Yang, P.S. Brandon, and A.C. Sidwell, eds. Smart \& Sustainable Built Environments. Oxford, UK.: Blackwell Publishing Ltd, 1-8.

Höök, M. and Stehn, L., 2008. Lean principles in industrialized housing production: the need for a 26 
483 Howell, G. and Ballard, G., 1998. Implementing construction: understanding and action. Proceedings International Group for Lean Construction, 0, 9.

Howell, G.A., 1999. What is Lean Construction. In: I.D. Tommelein, ed. IGLC 2012 - 20th Conference of the International Group for Lean Construction. University of California Berkeley, California,

Hyde, K.F., 2000. Recognising deductive processes in qualitative research. Qualitative Market USA.

Kolo, S.J., Rahimian, F.P., and Goulding, J.S., 2014. Housing delivery in Nigeria and the opportunity

$$
\text { Research: An International Journal, } 3 \text { (2), 82-90. }
$$

$$
\text { for offsite manufacturing. In: Creative Construction Conference. 85-90. }
$$

493 Larsson, J. and Simonsson, P., 2012. Barriers and drivers for increased use of off-site bridge 494 construction in Sweden. In: 28th Annual ARCOM Conference. Edinburgh, UK: Association of

Lawson, M., Ogden, R., and Goodier, C., 2010. Design in Modular Construction. Taylor \& Francis Researchers in Construction Management, 751-761.

Liu, Z., Osmani, M., Demian, P., and Baldwin, A.N., 2011. The potential use of BIM to aid construction waste minimalisation. In:-Sophia Antipolis, ed. Proceedings of the CIB W78-W102 Group. 2011. France.

Mao, C., Shen, Q., Shen, L., and Tang, L., 2013. Comparative study of greenhouse gas emissions between off-site prefabrication and conventional construction methods: Two case studies of residential projects. Energy \& Buildings, 66, 165-176. 
504 Meiling, J., Backlund, F., and Johnsson, H., 2012. Managing for continuous improvement in off-site construction: Evaluation of lean management principles. Engineering, Construction and Architectural Management, 19 (2), 141-158.

Melton, T., 2005. The benefits of lean manufacturing: What lean thinking has to offer the process industries. Chemical Engineering Research and Design, 83 (6 A), 662-673.

509 Miles, J. and Whitehouse, N., 2013. Offsite Housing Review. London.

510 Mossman, A., 2009. Creating value: A sufficient way to eliminate waste in lean design and lean production. Lean Construction Journal, 2009, 13-23.

512 Murugaiah, U., Benjamin, S.J., and Marathamuthu, M.S., 2010. Scrap loss reduction using the 5-whys analysis. International Journal of Quality \& Reliability Management, 27 (5), 527-540.

514 Nahmens, I. and Ikuma, L.H., 2012. Effects of Lean Construction on Sustainability of Modular Homebuilding. Journal of Architectural Engineering, 18 (2), 155-163.

Nikakhtar, A., Hosseini, A.A., Wong, K.Y., and Zavichi, A., 2015. Application of lean construction principles to reduce construction process waste using computer simulation: A case study.

Nurcan, S., Etien, A., Kaabi, R., Zoukar, I., and Rolland, C., 2005. A strategy driven business process modelling approach. Business Process Management Journal, 11 (6), 628-649.

Ozaki, R., 2003. Customer-focused approaches to innovation in housebuilding. Construction Management and Economics, 21, 557-564.

Pan, W., Gibb, A.G.F., and Dainty, A.R.J., 2008. Leading UK housebuilders' utilisation of offsite modern methods of construction. Building Research \& Information. 
527 Pan, W. and Sidwell, R., 2011. Demystifying the cost barriers to offsite construction in the UK. Construction Management \& Economics, 29, 1081-1099.

529 Pasquire, C.L. and Connolly, G.E., 2002. Leaner construction through off-site manufacturing. In: $530 \quad$ Proceedings 10th of the International Group of Lean Construction Conference, Gramado, Brazil. $1-13$.

Pearce, A., Pons, D., and Neitzert, T., 2018. Implementing lean-Outcomes from SME case studies. Operations Research Perspectives, 5, 94-104.

534 Quale, J., Eckelman, M.J., Williams, K.W., Sloditskie, G., and Zimmerman, J.B., 2012. Construction Matters Comparing Environmental Impacts of Building Modular and Conventional Homes in the

Sarvimaki, M., 2017. Case Study Strategies for Architects and Designers: Integrative Data Research Methods: Integrative Data Research Methods. London: Taylor \& Francis Group.

Schell, C., 1992. The Value of the Case Study as a Research Strategy.

540 Shamsuddin, S.M., Zakaria, R., and Mohamed, S.F., 2013. Economic Attributes in Industrialised

Shang, G. and Sui Pheng, L., 2014. Barriers to lean implementation in the construction industry in Building System in Malaysia. Procedia - Social and Behavioral Sciences, 105, 75-84.

544 Shi, J.J., Lee, D.E., and Kuruku, E., 2008. Task-based modeling method for construction business China. Journal of Technology Management in China, 9 (2), 155-173. process modeling and automation. Automation in Construction, 17 (5), 633-640.

Sundar, R., Balaji, A.N., and Satheesh Kumar, R.M., 2014. A review on lean manufacturing implementation techniques. Procedia Engineering, 97, 1875-1885. 
548 Vernikos, V.K., Nelson, R., Goodier, C.I., and Robery, P.C., 2013. Implementing an offsite 549 construction strategy: a UK contracting organisation case study. In: Proceedings of the 29th $550 \quad$ Annual ARCOM Conference. Reading, UK, 667-677.

551 Wahab, A.N.A., Mukhtar, M., and Sulaiman, R., 2013. A Conceptual Model of Lean Manufacturing Dimensions. Procedia Technology, 11 (ICEEI), 1292-1298.

553 Wilson, L., 2010. How to Implement Lean Manufacturing. New York: McGraw Hill.

554 Yin, R.K., 2009. Case Study Research: Design and methods. Fourth. London: SAGE Publications.

555 Yin, R.K., 2016. Qualitative Research from Start to Finish. Second Edi. London: Guilford $556 \quad$ Publications.

557 Zakaria, S.A., Gajendran, T., Rose, T., and Brewer, G., 2018. Contextual, structural and behavioural 558 factors influencing the adoption of industrialised building systems: a review. Architectural Engineering and Design Management, 14 (1-2), 3-26.

560 Zhang, Y., Fan, G., Lei, Z., Han, S., Raimondi, C., Al-Hussein, M., and Bouferguene, A., 2016. Leanbased diagnosis and improvement for offsite construction factory manufacturing facilities. In: ISARC 2016 - 33rd International Symposium on Automation and Robotics in Construction. 1090-

564 Zhang, Y., Lei, Z., Han, S., Bouferguene, A., and Al-Hussein, M., 2020. Process-Oriented Framework to Improve Modular and Offsite Construction Manufacturing Performance. Journal of Construction Engineering and Management, 146 (9). 